\title{
IDENTIFIKASI FAKTOR -FAKTOR YANG MEMPENGARUHI PENGAMBILAN KEPUTUSAN DALAM PENGADOPSIAN PAKET TEKNOLOGI BUDIDAYA UDANG DI TANAH LAUT KALIMANTAN SELATAN.
}

\author{
Achmad Azizi dan Hikmah ${ }^{1}$
}

\begin{abstract}
ABSTRAK
Riset ini bertujuan untuk mempelajari faktor-faktor yang mempengaruhi pengambilan keputusan dalam pengadopsian paket teknologi budidaya udang telah dilakukan pada tahun 2006 di kabupaten Tanah Laut, lokasi riset adalah Kabupaten Tanah Laut Propinsi Kalimantan Selatan. Riset Ini menggunakan metoda survey. Data yang dikumpulkan dalam riset ini adalah data primer dan data sekunder. Data primer diperoleh melalui wawancara menggunakan kuesioner terstruktur kepada responden, Jumlah responden dalam riset ini adalah 30 orang. Disamping itu dalam riset ini untuk mengali informasi melibatkan pembudidaya udang, tokoh masyarakat, kelembagaan terkait dan Dinas Perikanan setempat serta observasi lapangan. Hasil Riset menunjukkan bahwa faktor faktor yang mempangaruhi pengambilan keputusan secara diskriptif adalah 66,66 \% keputusan diambil secara individu. Akan tetapi apabila dilihat dari karakteristik internal hasil analisis statistk, koefisien korelasi (rs) faktor faktor yang mempengaruhi pengambilan keputusan dalam pengadopsian paket teknologi budidaya udang adalah umur $\left(0,820^{* *}\right)$, pendidikan formal $(0,529)$, tingkat pendapatan $\left(0,821^{* *}\right)$, kekosmopolitan $\left(0,785^{* *}\right)$, pengalaman berusaha $\left(0,660^{* *}\right)$, pola nafkah $\left(0,744^{* *}\right)$ dan tingkat kepercayaan $\left(0,486^{*}\right)$. Kemudian apabila dilihat dari faktor eksternal, faktor yang mempengaruhi adalah keuntungan $\left(0,789^{* *}\right)$, mudah untuk diusahakan $\left(0,493^{*}\right)$, referensi group $\left(0,724^{* *}\right)$, akses modal $\left(0,747^{* *}\right)$ dan ketersediaan informasi. $\left(0,818^{* *}\right)$. Hal ini memperlihatkan bahwa faktor tersebur mempunyai hubungan yang erat pengambilan keputusan
\end{abstract}

Kata Kunci : Faktor Pengadopsian, Budidaya, Paket Teknologi, Udang, Internal dan Eksternal.

Abstract: Indentification of Factor Enfluencing to Decision Making Process in the Adoption of Shrimp Culture Technological Package in the Tanah Laut, Kalimantan Selatan. By: Achmad Azizi and Hikmah.

This research aimed to study factors enfluencing decision making process in adopting technological package of shrimp culture in 2006. The research was done in Tanah Laut, the district in South Kalimantan. The research used survey method, Primary and secondary data were used in this study. Primary data were collected by interview using structured questionaire to 30 respondents, consisting of shrimp farmer, informal social leader and related institution. Result of the study showed that factors that influence decision making were taken individually $(66,66 \%)$. Moreover, it can be seen from internal characteristic of coefficient corelation statistic by which, factors that influence decision making in shrimp culture technology package adopting were age $\left(0,820^{* *}\right)$, formal education $(0,529)$, income level $\left(0,821^{* *}\right)$, cosmopolitan $\left(0,785^{* *}\right)$, capital access $\left(0,747^{* *}\right)$ and information availibility $\left(0,818^{* *}\right)$. It showed that those factors have a tight relationship with decision making business.

Keyword : Adopting Factors, Culture, Technology Package, Shrimp, Internal And External.

\footnotetext{
${ }^{1}$ Peneliti pada Balai Besar Riset Sosial Ekonomi Kelautan dan Perikanan JI. KS. Tubun Petamburan VI, Jakarta 10260

Telp. $02153650162 / F a x .02153650159$
} 


\section{PENDAHULUAN}

Kabupaten Tanah Laut merupakan salah satu kabupaten di kalimantan yang memdapatkan introduksi peket teknologi budidaa ikan berkisar pada tahun 2005. Sedangkan Program Intensifikasi Pembudidayaan Ikan dimulai pada tahun 2002 (INBUDKAN), program ini merupakan salah satu program utama dalam pembangunan perikanan budidaya yang tujuannya adalah untuk meningkatkan mutu produksi dan produktifitas usaha pembudidayaan ikan secara efesien dan berkelanjutan. Dalam pelaksanaannya, program INBUDKAN diarahkan pada gerakan bersama dari berbagai pihak terkait untuk mengembangkan usaha pembudidayaan ikan dan dilaksanakan atas dasar kerjasama antar anggota kelompok pembudidaya ikan (POKDAKAN) sebagai peserta program didalam kawasan.

Hasil evaluasi Direktorat Jenderal Budidaya diketahui bahwa pelaksanaan program inbudkan belum menunjukkan hasil yang diharapkan baik dalam pencapaian luas areal budidaya maupun hasil produksi. Sedangkan hasil riset mengungkapkan bahwa tingkat adopsi paket teknologi budidaya udang di beberapa lokasi Inbudkan tingkat adopsi teknologi masih dalam kategori sedang, hal ini dikarenakan lebih dari $50 \%$ responden tidak mengikuti aturan paket yang dianjurkan (Erlina, dkk 2003), didampng itu sering terjadi Dissonansi (Ketidakselarasan) antara paket anjuran dengan pelaksanaan yang dilakukan oleh pembudidaya ini menyebabkan tingkat keberhasilan pelaksanaan inbudkan tidak sesuai dengan yang diharapkan.

Rendahnya tingkat adopsi diopengaruhi oleh beberapa masalah seperti tingkat pengetahuan yang masih rendah, pekerjaan yang turun temurun, akan tetapi menurut Subagio dalam Istina (1988) mengemukakan bahwa prilaku komunikasi petani selalu berkaitan dengan usaha untuk mendapatkan informasi teknologi usahatani sebagai bahan pertimbangan untuk mengambil keputusan inovasi. Tahapan dalam pengambilan keputusan inovasi terdiri dari tahap pengenalan, tahap persuasi, tahap keputusan, tahap implementasi dan tahap konfirmasi. Sedangkan menurut Rogers dan Shoemaker (1971) pengambilan keputusan dipengaruhi oleh faktor internal yang berasal dari petani dan faktor eksternal yang berada diluar kendali petani. Jika terdapat perbedaan antara sikap seseorang terhadap inovasi dengan keputusan yang dibuatnya maka terjadilah dissonansi (ketidakselarasan) inovasi. Dissonansi inovasi merupakan tipe ketakselarasan kognitif yang khusus, dan menurut penyelidikan Festinger bahwa ada kecenderungan untuk mengurangi ketakselarasan itu (Hanafi, 1981).

Beranjak dari permasalah diatas tersebut di atas, maka perlu dilakukan kajian yang mendalam tentang faktor-faktor mempengaruhi dalam proses pengambilan keputusan mengadopsi paket teknologi. Selain itu untuk memberi gambaran tentang bagaimana pembudidaya udang. Gambaran proses pengambilan keputusan tersebut diharapkan bisa dijadikan bahan pertimbangan bagi metode transfer teknologi yang harus dilakukan oleh penyuluh Riset ini bertujuan untuk mempelajari faktor-faktor yang berhubungan dengan pengambilan keputusan dalam pengadopsian paket teknologi budidaya udang.

\section{METODOLOGI}

\section{Kerangka Pemikiran}

Kebijakan pemerintah dalam membuat program intensifikasi budidaya udang di tuangkan dalam bentuk petujuk teknis intensifikasi budidaya udang sebagai satu paket teknologi yang dianjurkan yang telah di bakukan dalam Standar Nasional Indonesia (SNI). Didalam proses tranformasi teknologi ini, bagaimana mekanisme transfer teknologi tersebut hingga sampai dan dapat diterima masyarakat pembudidaya udang juga sangat 
dipengaruhi oleh karakteristik internal dan eksternal masyarakat (bagaimana respon masayarakat, pemahamannya terhadap suatu masalah, bagaimana dia mencari informasi untuk memecahkan masalah dan bagaimana penilaian alternif solusi), hingga sampai pada tahap pengambilan keputusan penerapan paket teknologi budidaya udang. Dari proses tersebut akan dikaji apakah terjadi dissonansi inovasi (ketidakselaran inovasi).

Secara diagramatis kerangka pemikiran pengambilan Keputusan Pengadopsian Paket Teknologi Budidaya Perikanan dapat dilihat pada gambar 1 .

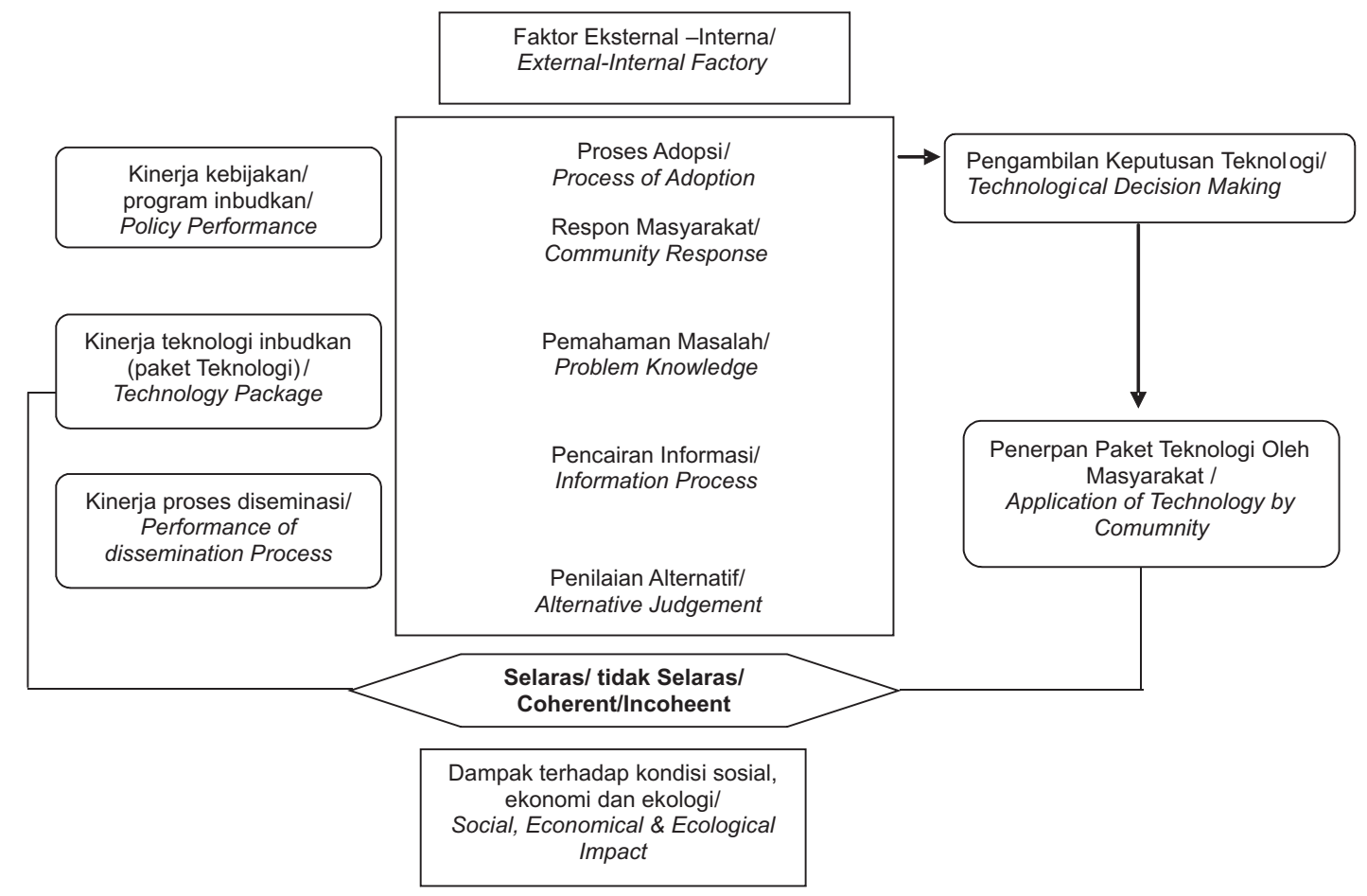

\section{Gambar 1. Kerangka Pemikiran Riset Dissonansi Inovasi Pengambilan Keputusan Adopsi Teknologi Perikanan Budidaya.}

picture 1. Research Framework for Innovation Dissonance of the Decision Making on Adopting Aquaculture Technology.

Waktu Pelaksanaan Kegiatan dan Lokasi Riset

Pelaksanaan riset kajian faktor-faktor yang mempengaruhi pengambilan keputusan pengadopsian paket teknologi budidaya udang dilakukan pada tahun 2006 lokasi riset ditentukan berdasarkan kondisi bahwa daerah tersebut merupakan daerah introduksi paket teknologi Perikanan Budidaya yang dituangkan dalam Program Intensifikasi Pemudidayaan Ikan (Inbudkan). Selain itu lokasi tersebut merupakan lokasi yang diharapkan dapat memberikan gambaran perkembangkan budidaya udang. Adapun lokasi tersebut adalah kabupaten Tanah Laut Propinsi Kalimantan Selatan.

\section{Populasi Riset dan Teknik Pengambilan Contoh}

Program Inbudkan komoditi udang pembudidaya udang yang aktif melakukan usaha budidaya di lokasi riset. Sehingga populasi riset adalah. 
Sample diambil secara stratified random sampling, dengan klasifikasi yang menjadi acuan adalah jenis teknologi INBUD udang yang dikenalkan yaitu teknologi sederhana (U1), madya (U2).

\section{Metode Pengumpulan Data}

Data yang dikumpulkan dalam riset ini adalah data primer dan data sekunder. Data primer diperoleh melalui wawancara menggunakan kuesioner terstruktur kepada responden, dan Focus Group Discussion yang melibatkan pembudidaya udang, tokoh masyarakat, kelembagaan terkait dan Dinas Perikanan setempat serta observasi lapangan. Data primer yang dikumpulkan yang dapat memepengaruhi pengadopsian paket teknologi adalah meliputi umur, tingkat pendidikan, pengalaman usaha, pendapatan, pola nafkah dan kekomospolitan, sedangkan data sekunder dikumpulkan dari laporan tahunan dan statistik Dinas Perikabnan Propinsi dan kabupaten dan laporan-laporan hasil riset sebelumnya.

\section{Analisa Data}

Data yang dikumpulkan, ditabulasi dan kemudian dianalisis menurut kebutuhan dalam pembahasan. Dalam riset ini digunakan dua pendekatan analisis yang berbeda: Pertama, untuk mengetahui tipe pengambilan keputusan pembudidaya untuk mengadopsi paket teknologi perikanan budidaya dan menganalisis terjadinya dissonansi inovasi pengguna teknologi perikanan digunakan pendekatan analisis deskriptif dan Kedua, untuk mengetahui faktor-faktor yang berhubungan antar peubah dalam setiap tahapan tipe pengambilan keputusan inovasi digunakan uji statistik non parametrik Rank Spearman (rs).

\section{HASIL DAN PEMBAHASAN}

\section{Profil Tanah Laut}

Lokasi areal tambak udang INBUDKAN di Kalimantan Selatan terkonsentrasi di tiga (3) kabupaten yaitu Kabupaten Kota Baru, Tanah Bumbu dan Kabupaten Tanah Laut. Perincian sasaran pelaksanaan kegiatan program intensifikasi pembudidaya udang pada tahun 2005 dapat dilihat pada tabel 1 berikut:

\section{Paket Teknologi}

Paket Teknologi yang dianjurkan dari program INBUDKAN adalah teknologi Itensif (U1), Semi itensif (U2), dan tradisional (U3). Namun teknologi yang digunakan masyarakat

Tabel 1. Keragaan Pelaksanaan Program Intensifikasi Pembudidaya Udang 2005.

Table 1. Performance of the Shrimp Culture Intensification, 2005.

\begin{tabular}{|c|c|c|c|c|}
\hline No & $\begin{array}{c}\text { Kabupaten/ } \\
\text { Rejency }\end{array}$ & $\begin{array}{c}\text { Teknologi/ } \\
\text { Technolgy }\end{array}$ & $\begin{array}{l}\text { Realisasi Areal/ } \\
\text { Areal Relatation } \\
\text { (ha) }\end{array}$ & $\begin{array}{c}\text { Realisasi Produksi/ } \\
\text { Produck Realitation } \\
\text { (ton) }\end{array}$ \\
\hline & & U1 & 500 & 200 \\
\hline \multirow[t]{3}{*}{1.} & Kotabaru & U2 & 1.000 & 900 \\
\hline & & Jumlah/Total & 1.500 & 1.100 \\
\hline & & U1 & 1.126 & 450 \\
\hline \multirow[t]{3}{*}{2.} & Tanah Laut & U2 & 888 & 800 \\
\hline & & Jumlah/Total & 2.014 & 1.250 \\
\hline & & U1 & 376 & 150 \\
\hline \multirow[t]{3}{*}{3.} & Tanah Bumbu & U2 & 500 & 450 \\
\hline & & Jumlah/Total & 876 & 600 \\
\hline & \multicolumn{2}{|c|}{ Jumlah/Total } & 4.390 & 2.950 \\
\hline
\end{tabular}

Sumber: Sub Dinas Produksi dan Pengembangan Teknologi (2005)/

Source : Sub Intecifition of Technology Development and Production(2005). 
petani tambak di Kalimantan Selatan khususnya di Kabupaten Tanah Laut hanyalah teknologi tradisional (U1). Sebelumnya pada tahun 2002, mereka pernah melakukan budidaya udang dengan teknologi semi intensif (U2), tetapi mengalami kegagalan. Hal ini disebabkan oleh hama penyakit virus white sport. Sehingga petani tambak banyak sekali mengalami kerugian. Akhirnya, masyarakat lebih suka menggunakan teknologi tradisional. Selain dari segi biaya produksi yang masih terjangkau oleh petani tambak, juga pengelolaannya juga tidak membutuhkan tenaga kerja yang banyak.

Berkaitan dengan penerapan inovasi baru, para petani tambak di Kalimantan Selatan sudah sangat terbuka dan ingin mencoba. Namun demikian, banyak faktor yang mempengaruhi pengambilan keputusan para petani tambak untuk menerapkan teknologi anjuran dari INBUDKAN.

\section{Tipe Pengambilan Keputusan di Tanah Laut}

Pengambilan keputusan senantiasa ada dan diperlukan dalam kegiatan sehari-hari baik tingkat individu, kelompok, kelurga, maupun organisasi. Atmosudidjo (1982) mengemukakan bahwa pengambilan keputusan adalah aktivitas pemilihan diantara sejumlah kemungkinan untuk menyelesaikan suatu masalah, pertentangan atau kebimbangan. Keputusan adalah hasil dari proses pengambilan keputusan. Dalam kaitannya dengan inovasi. Rogers,1983 mengemukakan bahwa ada 3 tipe pengambilan keputusan terhadap inovasi yakni: 1). Suatu pengambilan keputusan yang mandiri, dalam arti keputusan pemilihan untuk adopsi atau menolak inovasi, diambil oleh seseorang secara bebas, lepas dari keputusan anggota sistemnya (faktor prediposisi individu itu sendiri), 2). Pengambilan keputusan secara kolektif, karena pemilihan untuk melakukan adopsi atau menolak inovasi adalah hasil keputusan bersama diantara anggota sistem, 3). Pengambilan keputusan oleh penguasa, karena keputusan untuk menerima atau menolak inovasi dibuat oleh beberapa individu yang mempunyai kekuasaan dan status, atau oleh para ahli dibidang teknologi.

Dalam proses pengambilan keputusan untuk menerima atau menolak suatu paket teknologi perlu adanya tipe personal untuk memerankan berbagai peran dalam dalam pola adopsi difusi teknologi. Personal tersebut berperan satu sama lain untuk membantu membuat keputusan menerima atau menolak adopsi inovasi. Tipe personal tersebut adalah Inovator, Pembicara (Talker), Opinion Leader

Inovator, pembicara (talker), dan opinion leader mempunyai peran yang sangat penting dalam proses pengambilan keputusan menerima atau menolak untuk mengadopsi teknologi, dan ketiga tipe personal tersebut juga sangat berpengaruh untuk meminimalisir terjadinya dissonansi inovasi.

Berkaitannya dengan proses adopsi teknologi budidaya udang, tipe pengambilan keputusan sangat mempengaruhi kecepatan adopsi. Jika keputusan adopsi dilakukan secara individu (mandiri) akan relatif lebih cepat dibanding pengambilan keputusan berdasarkan keputusan bersama (kelompok). Disamping itu, proses pengambilan keputusan untuk mengadopsi teknologi budidaya udang sebaiknya secara normal dengan tidak mengambil jalan pintas atau melekatkan tahap-tahap dalam proses adopsi.

Dalam penelitian ini, ada enam jenis keputusan inovasi teknologi budidaya udang yang menjadi parameter yaitu : 1) keputusan jenis teknologi yang digunakan, 2) keputusan konstruksi tambak, 3) keputusan pemberian pakan, 4). keputusan dalam pengendalian penyakit, 5) keputusan panen, dan 6) keputusan pemasaran. Secara deskriptif, tipe pengambilan keputusan yang dibuat oleh petani tambak udang di masing-masing lokasi penelitian adalah sebagai berikut:

Teknologi yang digunakan masyarakat petani tambak di Kabupaten Tanah Laut adalah teknologi tradisional (U1). Sebelumnya pada tahun 2002, mereka pernah 
melakukan budidaya udang dengan teknologi semi intensif (U2), akan tetapi untuk mengalami kegagalan yang disebabkan terserangnya oleh hama penyakit virus white sport, sehingga petani tambak banyak sekali mengalami kerugian. Akhirnya, masyarakat lebih suka menggunakan teknologi tradisional. Selain dari segi biaya produksi yang masih terjangkau oleh petani tambak, juga pengelolaannya juga tidak membutuhkan tenaga kerja yang banyak. Tipe pengambilan keputusan pada tahapan budidaya udang yang dilakukan petani tambak udang di Tanah Laut, tergambar pada tabel berikut ini.

Tabel 2 di atas memperlihatkan bahwa $66,66 \%$ pengambilan keputusanpenerapan paket teknologi diambil secara individu, yaitu keputusan dalam menentukan jenis teknologi yang digunakan, pemberian pakan, waktu panen dan jalur pemasaran. Keputusan dalam menentukan jenis teknologi yang digunakan dan pemberian pakan diserahkan kepada petambak karena berkaitan dengan kemampuan petambak dalam hal finasial dan keterampilan yang dimiliki oleh masingmasing petambak. Sedangkan keputusan menentukan waktu panen dan pemasaran lebih ditentukan oleh kebiasaan petambak selama ini. Umumnya mereka sudah mempunyai jalur pemasaran sendiri dengan spesifikasi hasil panen yang telah disepakati antara pembeli dan petambak, sehingga mereka tidak memerlukan intervensi dari pihak lain.

Keputusan dalam menentukan kontruksi tambak dilakukan petambak berdasarkan pada petunjuk dari petugas program inbudkan, dalam hal ini adalah Tenaga Pendamping Teknologi (TPT) yang merupakan kepanjangan tangan dari pemerintah. TPT merupakan tenaga kontrak yang ditugaskan khusus untuk memfasilitasi kegiatan program Inbudkan di tingkat petambak. Kondisi ini didukung pula oleh karakter petambak udang Tanah laut yang sangat terbuka terhadap inovasi baru yang berkaitan dengan budidaya

\section{Tabel 2. Tipe Pengambilan Keputusan Penerapan Teknologi Budidaya Udang di Kabupaten Tanah Laut.}

Table 2. Type of Decission Making on the Application of Shrimp Culture Technology in Tanah Laut District.

\section{Jenis Keputusan/ Type of Decission}

Keputusan dalam menentukan jenis

teknologi yang digunakan/

Decission on type of technology

Keputusan dalam menentukan konstruksi tambak/

Decission of pond construction

Keputusan dalamPemeliharaan

pemberian pakan/ Decission on culture

feeding

Pengendalian penyakit/Disease control

Keputusan dalam menentukan panen/

Decission on time of harvest

Keputusan dalam pemasaran/

Decission on marketing

Persentase/ Percentage (\%)/

Tipe pengambilan Keputusan/

Type of Decission Making

Individu/ Kelompok/ Pemerintah/

Individual Group Government

V

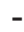

V

- $\quad V$

V

V

66,66 
udang, namun karena keterbatasan modal mereka hanya melakukan budidaya udang sistem tradisonal (U1).

Peranan Kelompok Tani Tambak dalam pengambilan keputusan adalah sebesar 16,67 $\%$ yaitu pada tahap pengambilan keputusan dalam penanggulangan hama penyakit. Ketika terserang suatu penyakit petambak umumnya mendatangi kelompok tani dan saling bertukar pikiran dalam penanggulangannya. Biasanya apabila penyakit yang menyerang udang ditambak yang bersifat massal, artinya menyerang seluruh petambak dilokasi tersebut dan apabila petani dan Kelompok tidak bisa menangani maka mereka akan mengunjungi dinas terkait untuk mengkonsultasikannya.

\section{Hubungan Karakteristik Internal Dan Ekternal Dengan Pengambilan Keputusan Pengadopsian Paket Teknologi Budidaya Udang}

Hubungan karakteristik internal dan eksternal pempunyai peranan yang sangat penting dalam pengabilan keputusan pengadopsian paket teknologi yang dianjurkan. Menurut Jahi (1991) mengemukakan bahwa, proses adopsi inovasi adalah merupakan suatu proses pengambilan keputusan untuk mengadopsi suatu inovasi, yaitu suatu sikap mental melalui proses seseorang mengetahui adanya suatu inovasi sampai saat ia membuat keputusan untuk mengadopsi atau menolak dan memperkuat keputusan tersebut. Dalam proses ini, banyak faktor yang mempengaruhinya, salah satunya adalah karakteristi individu. Akan tetapi menurut Soekarwati (1988) bahwa pengambilan keputusan, seseorang menolak suatu inovasi adalah banyak tergantung pada sikap mental dan perbuatan yang dilandasi oleh situasi intern orang tersebut (misalnya pendidikan, umur, dan sebagainya) serta situasi ekstrn atau situasi lingkungannya, misalnya frekuensi kontak dengan sumber informasi, kesukaan mendengarkan radio atau menonton televisi dsb. Hal Senada juga diungkapkan oleh Slamet (1978), beberapa karakteristik individu yang turut mempengaruhi cepat lambatnya proses adopsi meliputi : umur, pendidikan, status sosial, pola hubungan (lokalit vs kosmopolitan), keberanian mengambil resiko dan sikap terhadap perubahan.

Hasil penelitian Latif (1995) menunjukkan bahwa faktor sosial ekonomi petani (tingkat pendidikan formal, pendidikan non formal, motivasi berusaha tani secara menetap, kekosmopolitan, dan pendapatan)dan sifatsifat inovasi ternyata mempunyai hubungan yang nyata dengan tingkat adopsi petani tentang berusaha tani menetap. Berbeda dengan pendapat Dixon (1992), yang menyatakan bahwa terdapat beberapa sifat individu yang sangat berperan dalam mempengaruhi tingkat dan kecepatan adopsi inovasi, yaitu: prasangka interpersonal, pandangan terhadap kondisi lingkungan yang terbatas, sikap terhadap penguasa, sikap kekeluargaan, fatalisme, kelemahan aspirasi, hanya berpikir untuk hari ini, kekosmopolitness, kurangnya kemampuan berpikir kritis dan tingkat kemajuan peradabannya.

Berdasarkan hasil analisis rank spearman, hubungngan faktor-faktor karakteristik Internal dan eksternal terhadap pengambilan keputusan pengadopsian teknologi budidaya udang pada masingmasing lokasi penelitian dapat dilihat pada tabel 3.

Berdasarkan hasil analisis data korelasi rank spearman terhadap karakteristik internal dan eksternal responden di Kabupaten Tanah Laut Tabel 3 menunjukkan bahwa faktor-faktor internal yang berhubungan dengan pengambilan keputusan adalah: faktor umur $\left(r s=0.820^{* *}\right)$, pendidikan formal $\left(r s=0,529^{* *}\right)$, pendapatan $\left(r s=0,821^{* *}\right)$, pengalaman berusaha $\left(r s=0.785^{* *}\right)$, kekosmopolitan $\left(r s=0.660^{* *}\right)$, pola nafkah $\left(r s=0.744^{* *}\right)$, tingkat kepercayaan $\left(r s=0.486^{* *}\right)$ dan orientasi nilai $\left(r s=0.876^{* *}\right)$. Sedangkan faktor karakteristik ekternal yang berpengaruh terhadap 
pengambilan adalah keuntungan relatif $\left(r s=0.789^{* *}\right)$, kemudahan untuk dicoba $\left(\mathrm{rs}=0.493\right.$, reference group $\left(\mathrm{rs}=0.724^{* *}\right)$, akses modal $\left(\mathrm{rs}=0.737^{* \star}\right)$ dan ketersediaan sumber informasi $\left(\mathrm{rs}=0.818^{\star *}\right)$.

\section{Faktor faktor Internal Dalam Pengambilan Keputuasan}

Dalam pengabilan keputusan pengadopsisn paket teknologi budidaya udang tidak hanya dilakukan dengan menggunakan analisis Rank Spearman, akan tetapi dilakukan dengan analisis secara diskriptif untuk melihat gambaran pengambilan keputusan seperti Faktor umur, tingkat pendidikan, Tingkat pendapatan, kekosmopolitan, pengalaman berusaha, pola nafkah dan tingkat kepercayaan.
Umur

Kisaran umur responden pembudidaya udang di Tanah Laut adalah 37-54 tahun dengan sebaran responden pembudidaya seperti pada tabel 4 .

Tabel 4 memperlihatkan bahwa persentase umur responden pembudidaya yang tergolong dalam kategori sangat produktif adalah $75 \%$, tergolong usia produktif $25 \%$ dan tergolong kategori tidak produktif 0 $\%$.

Umur responden pembudiya udang di Tanah Laut yang dominan tergolong kategori sangat produktif cenderung mempengaruhi pengambilan keputusannya untuk menggunakan teknologi yang dianjurkan. Hal ini didukung hasil analisis rank spearman yang memperlihatkan bahwa nilai koefisien korelasi

Tabel 3. Hubungan Karakteristik Internal dengan Pengambilan Keputusan Pembudidaya dalam Menerapkan Paket Teknologi INBUD Udang.

Table 3. Relationship between Internal Characteristics and Decision Making of Shrimp Farmers in Appliying the Shrimp Culture Technology.

\begin{tabular}{lr}
\hline \multicolumn{1}{c}{$\begin{array}{c}\text { Karakterisitik Individu/ } \\
\text { Individual Characteristics }\end{array}$} & $\begin{array}{c}\text { Koefisien Korelasi (rs)/ } \\
\text { Coefficent of Corelation }\end{array}$ \\
\hline Factor Internal/ Internal Factory & \\
Umur/Age & $0.820^{* *}$ \\
Pendidikan Formal/Formal Education & $0.529^{* *}$ \\
Pendapatan/Income & $0.821^{* *}$ \\
Jumlah Tanggungan Keluarga / Family Members & -0.295 \\
Pengalaman Berusaha Budidaya / Experience & $0.785^{* *}$ \\
Kekosmopolitan/Cosmopolitance & $0.660^{* *}$ \\
Pola Nafkah/ Earning Pattern & $0.744^{* *}$ \\
Tingkat Kepercayaan/ Leve/ of Trust & $0.486^{*}$ \\
Status Lahan/ Land Status & 0.193 \\
Keberanian Mengambil Resiko/ & 0.08 \\
Orientasi Nilai & 0.002 \\
Faktor Eksternal/ External Factory & \\
Ciri Inovasi/ Inovation Characteristics & \\
- Keuntungan/Profit & $0.789^{* *}$ \\
- Kesesuaian/Switability & 0.306 \\
- Kemudahan untuk dicoba/Easiness & $0.493^{*}$ \\
Keikutsertaan dalam kelompok/Group Involvement & 0.021 \\
Reference Group/ Group Reference & $0.724^{* *}$ \\
Akses Modal/ Capital Access & $0.747^{* *}$ \\
Ketersediaan sumber infomasi/Avilability of sourch of information & $0.818^{* *}$ \\
\hline
\end{tabular}


Tabel 4. Keadaan Umur Responden Pembudidaya Udang di Tanah Laut.

Table 4. Age Characteristics of Respondent of Shrimp Farmer in Tanah Laut.

\begin{tabular}{|c|c|c|c|}
\hline \multirow{2}{*}{ No } & \multirow{2}{*}{ Kriteria/Criteria } & \multicolumn{2}{|c|}{ Responden/ Respondents } \\
\hline & & Jumlah/Total & Persentase/ Percentage (\%) \\
\hline 1 & $\begin{array}{l}\text { Sangat produktif / Higly Productive } \\
\text { ( } 25-45 \text { th) }\end{array}$ & 15 & 75 \\
\hline 2 & Produktif/Productive ( 46 th- 65 th) & 5 & 25 \\
\hline 3 & $\begin{array}{l}\text { Tidak Produktif/ Non Productive }(<25 \\
\text { th dan }>65 \text { th) }\end{array}$ & 0 & 0 \\
\hline & Jumlah/Total & 20 & 100 \\
\hline
\end{tabular}

umur dengan pengambilan keputusan pada taraf uji $99 \%$ adalah $\left(r s=0.535^{* *}\right.$ ). Ini artinya terdapat hubungan yang nyata antara umur dengan pengambilan keputusan inovasi. Hal ini mengindikasikan bahwa semakin produktif responden pembudidaya, semakin tinggi pula pengambilan keputusannya terhadap inovasi budidaya udang. Eratnya hubungan antara umur dengan pengambilan keputusan inovasi teknologi budidaya udang diduga karena usia responden pembudidaya udang di Tanah Laut tergolong kategori usia yang sangat produktif. Dimana pada usia ini, responden lebih banyak memiliki kemampuan dalam mempelajari, memahami, menerima dan mengadopsi suatu inovasi, serta peningkatan produktivitas kerjanya.

\section{Tingkat Pendidikan Formal}

Tingkat pendidikan responden di Tanah Laut pada umum hanya sampai tamatan Sekolah Menengah Pertama, hasil analisis secara diskriptif yang mencapai pendidikan formal di atas SLTA tidak ada, sedangkan 70 $\%$ (14) responden memiliki pendidikan SLTP-
SLTA dan $30 \%$ (6) responden memiliki pendidikan dibawah SLTP. Keadaan tingkat pendidikan formal dapat dilihat pada tabel 5 .

Tabel 5 memperlihatkan bahwa persentase tingkat pendidikan responden pembudidaya udang di Tanah Laut yang tergolong kategori tinggi adalah $0 \%$, sedang $70 \%$ dan rendah $30 \%$. Pendidikan formal pembudidaya sebagai salah satu karakteristik individu juga terkait dengan pengetahuan, keterampilan dan produktivitas usaha budidaya udang. Responden yang mempunyai pendidikan yang lebih tinggi cenderung lebih dapat menerima dengan baik inovasi yang yang dianjurkan. Sedangkan responden yang berpendidikan lebih rendah keputusan inovasinya juga masih setengahsetengah. Seseorang yang memiliki pengetahuan dan kesadaran yang tinggi cenderung semakin tinggi juga keputusan inovasinya. Sehingga tinggi rendahnya pendidikan dapat menentukan tinggi tingkat pengambilan keputusan dalam pengadopsian paket teknologi.

Tabel 5 Keadaan Tingkat Pendidikan Formal Pembudidaya Udang di Tanah Laut. Table. 5. Formal Education Level of Shrimp Farmer in Tanah Laut.

\begin{tabular}{ccrc}
\hline \multirow{2}{*}{ No } & Kriteria/Criteria & 0 & \multicolumn{2}{c}{ Responden/ Respondents } \\
\cline { 3 - 4 } & & Jumlah/Total & $\begin{array}{c}\text { Persentase/ } \\
\text { Percentage (\%) }\end{array}$ \\
\hline 1 & Tinggi /High(>SLTA) & 14 & 70 \\
2 & Sedang/ Medium (SLTP)- SLTA & 6 & 30 \\
3 & Rendah/Low (<SLTP) & $\mathbf{2 0}$ & $\mathbf{1 0 0}$ \\
\hline
\end{tabular}


Berdasarkan hasil ananlisis rank spearman terdapat hubungan yang nyata antara tingkat pendidikan formal dengan pengambilan keputusan inovasi dengan nilai koefisien korelasi $\left(r s=0.529^{* *}\right)$. Hal ini mengindikasikan bahwa semakin tinggi tingkat pendidikan formal pembudidaya, semakin besar pula kecenderungan pembudidaya mengambil keputusan mengadopsi inovasi budidaya udang. Sehungga responden dapat dengan cepat untuk menentukan dalam pengambilan keputusan untuk menerima paket teknologi

\section{Tingkat Pendapatan}

Tingkat pendapatan responden pembudidaya di Tanah Laut berkisar antara Rp. 21.000.000,- sampai Rp.97.000.000,-. Dari kisaran tersebut rata-rata tinkat pendapatan pembudidaya tergolong kategori rendah. Keadaan tingkat pendapatan responden pembudidaya udang di Kabupaten Tanah Laut dapat dilihat pada Tabel 6.

Tabel 6 memperlihatkan bahwa tingkat pendapatan responden pembudidaya udang Tanah Laut lebih didominasi tingkat pendapatan rendah yaitu $80 \%$ responden berpenghasilan berkisar antara $\mathrm{Rp}$ 21.000,000 sampai Rp.46.333.333. sedangkan tingkat pendapatan yang tinggi dan sedang masing-masing hanya $10 \%$. . Hal ini disebabkan karena responden pembudidaya udang di Tanah Laut masih menggunakan teknologi sederhana (U1). Sehingga hasil yang didapat lebih sedikit dibandingkan dengan yang menggunakan teknologi madya (U2). Beberapa hal yang menjadi alasan pembudiaya udang di Tanah Laut tidak menggunakan teknologi Semi intensif dan intensif adalah karena keterbatasan modal, tidak mau mengambil resiko kerugian yang besar jika mengalami kekagagalan panen, tidak memiliki sarana dan prasarana yang lengkap untuk menerapkan teknologi maju. Penguatan modal dari pemerintah belum mencukupi biaya produksi untuk teknologi maju.

Berdasarkan uji analisis statistik rank spearman terhadap responden di Tanah Laut menunjukkan bahwa tingkat responden pembudidaya udang memiliki hubungan yang nyata pada taraf $99 \%$ terhadap pengambilan keputusan dengan nilai koefisen korelasi $\left(r s=0,821^{* *}\right)$. Hal ini mengindikasikan bahwa semakin tinggi tingkat pendapatan pembudidaya, semakin besar pula kecenderungan pembudidaya dalam memutuskan mengadopsi inovasi. Sebagian inovasi budidaya udang memerlukan sarana yang berkualitas baik dalam jumlah tertentu sehingga memerlukan biaya yang tinggi. Oleh sebab itu, semakin besar pendapatan pembudidaya semakin besar pula kesempatan dan kemampuan untuk menerapkan paket teknologi yang dianjurkan.

\section{Jumlah Tanggungan Keluarga}

Kisaran jumlah tanggungan keluarga pembudidaya udang adalah 2-7 orang. Sedangkan sebaran jumlah tanggungan

Tabel 6. Sebaran Tingkat Pendapatan Responden Pembudidaya Udang di Tanah Laut. Table 6. Distribution Level of Income Respondents of Shrimp Culture in Tanah Laut.

\begin{tabular}{ccrr}
\hline & Kriteria/Creiteria & & \multicolumn{2}{c}{ Responden/ Respondents } \\
\cline { 3 - 4 } No & $\begin{array}{c}\text { Jumlah/ } \\
\text { Total }\end{array}$ & $\begin{array}{c}\text { Persentasel } \\
\text { Presentage } \\
(\%)\end{array}$ \\
\hline 1 & Tinggi/High (Rp.71.666.667- Rp.97.000.000,-)/Thn & 2 & 10 \\
2 & Sedang/Medium (Rp. 46.333.334- Rp. 71.666.667)/Thn & 2 & 10 \\
3 & Rendah/Low (Rp.21.000.000- Rp.46.333.333)/Thn & 16 & 80 \\
& Jumlah/Total & $\mathbf{2 0}$ & $\mathbf{1 0 0}$ \\
\hline
\end{tabular}


Tabel 7. Sebaran Jumlah Tanggungan Keluarga Responden Pembudidaya Udang di Tanah Laut.

Table 7. Distribution Family Member of Shrimp Farmer in Tanah Laut.

\begin{tabular}{clrr}
\hline & \multirow{2}{*}{ No Kriteria/Criteria } & \multicolumn{2}{c}{ Responden/Respondents } \\
\cline { 3 - 4 } & & $\begin{array}{c}\text { Jumlah/ } \\
\text { Total }\end{array}$ & $\begin{array}{c}\text { Persentase/ } \\
\text { Presentage (\%) }\end{array}$ \\
\hline 1 Tinggi/High (>6 orang) & 3 & 15 \\
2 & Sedang/Medium (4-6 orang) & 9 & 45 \\
3 & Rendah/Low (1-3 orang) & 8 & 40 \\
& \multicolumn{1}{c}{ Jumlah/Total } & $\mathbf{2 0}$ & 100 \\
\hline
\end{tabular}

keluarga responden pembudidaya udang dapat dilihat pada tabel 7 , Tabel 7 menunjukkan bahwa jumlah tanggungan keluarga didominasi oleh kategori sedang dengan persentase $45 \%$. Sedangkan kategori rendah $40 \%$ dan kategori tinggi $15 \%$.

Jumlah tanggungan keluarga tidak memiliki hubungan yang nyata pada taraf uji $99 \%$. Hal ini dapat dilihat dari nilai koefisein korelasi ( $r s=-0.295)$. Dari nilai ini menunjukkan kecenderungan negatif, artinya semakin kecil jumlah tanggungan keluarga semakin respoden semakin ada kecenderungan pembudidaya udang mengambil keputusan inovasi secara mandiri.

\section{Pengalaman Berusaha}

Kisaran pengalaman responden pembudidaya udang adalah 7- 30 tahun. Sebaran pengalaman berusaha responden pembudidaya dapat dilihat pada tabel 8 .

Tabel 8 menunjukkan bahwa pengalaman berusaha responden pembudidaya udang didominasi kategori rendah dengan persentase $55 \%$ dan kisaran lama pengalaman adalah 1-10 tahun. Sedangkan kategori sedang $40 \%$ dengan kisaran lama pengalaman adalah 11-20 tahun dan kategori tinggi adalah $5 \%$ dengan kisaran lama pengalaman adalah 12-30 tahun.

Hasil uji statistik rank spearman menunjukkan bahwa pengalaman berusaha berkorelasi nyata pada taraf uji $99 \%$. Hal ini dapat dilihat dari nilai koefesien korelasi (rs= $\left.0.785^{* *}\right)$. Ini berarti bahwa semakin lama pengalaman sesorang dalam melakukan usaha budidaya, semakin tinggi pula keputusan untuk inovasi teknologi.

\section{Tingkat Kosmopolitan}

Tingkat kekosmopolitan pembudidaya udang dapat dilihat pada tabel 9

Tabel 9 menunjukkan bahwa tingkat kekosmopolitan responden pembudidaya udang di Tanah Laut yang tergolong rendah adalah $0 \%$, tergolong sedang $65 \%$ dan tergolong tinggi $35 \%$.

Tabel 8. Sebaran Pengalaman Berusaha Responden Pembudidaya Udang di Tanah Laut. Table 8. Distribution of Business Experience of Shrimp Farmer in Tanah Laut.

\begin{tabular}{cccc}
\hline \multirow{2}{*}{ No } & Kriteria/Creiteria & \multicolumn{2}{c}{ Responden/Respondents } \\
\cline { 3 - 4 } \multicolumn{2}{c}{} & Jumlah/Total & $\begin{array}{c}\text { Persentase/Presentage } \\
\text { (\%) }\end{array}$ \\
\hline 1 & Tinggi /High(21-30 tahun) & 8 & 5 \\
2 & Sedang/Medium (11-20tahun) & 11 & 40 \\
3 & Rendah /Low (1-10 tahun) & 20 & 55 \\
& Jumlah/Total & $\mathbf{2 0 0}$ \\
\hline
\end{tabular}


Tabel 9. Sebaran Tingkat Kekosmopolitan Responden Pembudidaya Udang di Tanah Laut. Table 9. Distribution Level of Cosmopolitance ofShrimp Farmer in Tanah Laut.

\begin{tabular}{|c|c|c|c|}
\hline \multirow[b]{2}{*}{ No } & \multirow[b]{2}{*}{ Kriteria/ Creiteria } & \multicolumn{2}{|c|}{ Responden/Respondents } \\
\hline & & Jumlah/Total & $\begin{array}{c}\text { Persentase/Presentage } \\
(\%)\end{array}$ \\
\hline & Tinggi/High(>10 kali) & 7 & 35 \\
\hline 2 & Sedang /Medium(4 - 10 kali) & 13 & 65 \\
\hline 3 & Rendah /Low(3 kali) & 0 & 0 \\
\hline & Jumlah/Total & 20 & 100 \\
\hline
\end{tabular}

Berkaitan dengan pengambilan keputusan penerapan teknologi budidaya udang di Tanah Laut, dari hasil analisis rank sperman diketahui bahwa kosmopolitan berhubungan nyata pada taraf uji $99 \%$ dengan pengambilan keputusan responden terhadap inovasi. Hal ini dapat dilihat dari nilai koefisien korelasi ( $\left.r s=0.660^{* *}\right)$. Ini berarti bahwa pengambilan keputusan responden pembudidaya udang cenderung dipengaruhi oleh tingkat kekosmopolitan.

\section{Pola Nafkah}

Pola nafkah masyarakat pembudidaya Tanah Laut bertumpu pada satu usaha yakni budidaya udang. Ada beberapa responden di Tanah Laut mempunyai usaha disamping sebagai pembudidaya udang, yakni sebagai penampung dan pedagang udang. Dari pola nafkah yang bertumpu pada satu usaha budidaya, sangat memungkinkan responden untuk mengambil keputusan mengadopsi inovasi teknologi budidaya udang. Sebaran pola nafkah responden pembudiaya udang di Tanah Laut dapat dilihat pada tabel 10.
Tabel 10 menunjukkan bahwa responden yang memiliki usaha hanya bertumpu pada usaha budidaya sebesar $70 \%$ sedangkan yang memiliki usaha budidaya dan non budidaya udang sebesar $30 \%$. Ini berarti sebagian besar pola nafkah responden bertumpu pada usaha budidaya udang.

Berkaitan dengan pengambilan keputusan penerapan teknologi budidaya udang, dari hasil analisis rank sperman diketahui bahwa pola nafkah berhubungan nyata pada taraf uji $99 \%$ terhadap pengambilan keputusan responden di Tanah Laut. Hal ini dapat dilihat dari nilai koefisien korelasi $\left(r s=0.744^{* *}\right)$. Ini berarti bahwa pengambilan keputusan responden pembudidaya udang cenderung dipengaruhi oleh pola nafkah.

\section{Tingkat Kepercayaan}

Tingkat kepercayaan responden terhadap suatu inovasi merupakan salah satu faktor seseorang mengadopsi suatu inovasi. Sebaran tingkat kepercayaan responden pembudidaya udang dapat dilihat di tabel 11.

Tabel 10. Sebaran Pola Nafkah Responden Pembudidaya Udang di Tanah Laut. Table 10, Distribution of Respondents Income Pattern of Shrimp Farmer in Tanah Laut.

\begin{tabular}{cccc}
\hline \multirow{2}{*}{ No Kriteria/Creiteria } & \multicolumn{2}{c}{ Responden/Respondents } \\
\cline { 3 - 4 } & Jumlah/Total & $\begin{array}{c}\text { Persentase/ } \\
\text { Presentage (\%) }\end{array}$ \\
\hline 1 Budidaya udang saja/Shrimp culture only & 14 & 70 \\
2 Budidaya udang dan Non Budidaya udang/ & 6 & 30 \\
Mixed culture & Jumlah/Total & $\mathbf{2 0}$ & 100 \\
\hline
\end{tabular}


Tabel 11. Sebaran Tingkat Kepercayaan Responden Pembudidaya Udang di Tanah Laut. Table 11. Distribution of Confidence Level of Shrimp Farmer in Tanah Laut .

\begin{tabular}{|c|c|c|c|}
\hline \multirow[b]{2}{*}{ No } & \multirow[b]{2}{*}{ Kriteria/ Creiteria } & \multicolumn{2}{|c|}{ Responden/Respondents } \\
\hline & & Jumlah/ Total & $\begin{array}{c}\text { Persentasel } \\
\text { Presentage (\%) }\end{array}$ \\
\hline & Tinggi /high & 3 & 15 \\
\hline 2 & Sedang /Medium & 13 & 65 \\
\hline 3 & Rendah /Low & 4 & 20 \\
\hline & Jumlah/Total & 20 & 100 \\
\hline
\end{tabular}

Tabel 11 menunjukkan bahwa tingkat kepercayaan pembudidaya udang didominasi katagori sedang dengan persentase $65 \%$. Sedangkan peresentase kategori tinggi adalah $15 \%$ dan persentase kategori rendah adalah $20 \%$. Hal ini mengindikasikan bahwa tingkat kepercayaan pembudidaya di Tanah Laut terhadap inovasi cukup tinggi. Sejauh ini responden pembudidaya cukup terbuka dan percaya dengan teknologi yang dianjurkan. Hanya kendala bagi pembuidaya udang di Tanah laut adalah modal. Sehingga selama ini mereka masih menggunakan paket teknologi tradisional (U1). Berdasarkan hasil analisis rank sperman, tidak terdapat hubungan yang signifikan antara tingkat kepercayaan dengan keputusan inovasi. Hal ini dapat dilihat dari nilai koefisen korelasi $\left(r s=0,486^{*}\right)$. Ini mengindikasikan bahwa semakin tinggi tingkat kepercayaan seseorang terhadap inovasi semakin tinggi pula tingkat pengambilan seseorang untuk mengadopsi inovasi.

\section{Keberanian Mengambil Resiko}

Tingkat keberanian mengambil resiko pembudiaya udang turut berpengaruh terhadap pengambilan keputusan pembudidaya dalam melakukan usaha budidaya udang. Di Tanah Laut, sebaran responden yang memiliki keberanian mengambil resiko dalam usaha budidaya dapat dilihat pada tabel 12 .

Tabel 12 menunjukkan bahwa tingkat keberanian mengambil resiko responden pembudidaya udang di Tanah Laut didominasi oleh kategori sedang dengan persentase responden $55 \%$, hal ini responden tidak mau mengalami kerugian ang sangat besar ang diakibatkan oleh serangan penakit. Sedangkan kategori rendah adalah $0 \%$, dan kategori tinggi $45 \%$. Meskipun pembudidaya udang di Tanah laut sering mengalami kegagalan, namun mereka tetap mau melakukan usaha budidaya udang. Karena menurut responden satu kali keberhasilan

\section{Tabel 12. Sebaran Responden Terhadap Tingkat Keberanian Mengambil Resiko Paket Teknologi Pembudidaya Udang di Tanah Laut.}

Table 12. Respondent Distributiont on Risk Taking of Technological Package of Shrimp Farmer in Tanah Laut.

\begin{tabular}{llrr}
\hline \multirow{2}{*}{ No } & Kriteria/ Creiteria & \multicolumn{2}{c}{ Responden/Respondents } \\
\cline { 3 - 4 } & & Jumlah/ Total & $\begin{array}{c}\text { Persentase/Presentage } \\
\text { (\%) }\end{array}$ \\
\hline 1 & Tinggi /High & 9 & 45 \\
2 & Sedang /Medium & 11 & 55 \\
3 & Rendah /low & 0 & 0 \\
& Jumlah/Total & $\mathbf{2 0}$ & $\mathbf{1 0 0}$ \\
\hline
\end{tabular}


panen dapat menutupi biaya kerugian dua kali kegagalan panen. Namun tentu saja teknologi yang mereka gunakan bukan teknologi maju. Karena teknologi maju biaya operasional lebih tinggi.

Dari hasi analisis rank sperman, tidak terdapat hubungan yang nyata pada taraf uji 99\% antara keberanian mengambil resiko dengan pengambilan keputusan inovasi. Hal ini dapat dilihat dari nilai koefisien korelasi $(r s=0.08)$. Ini menigindikasikan bahwa dalam proses pengambilan keputusan inovasi teknologi budidaya udang, semakin berani seseorang mengambil resiko terhadap kegagalan dalam usaha budidaya udang bukan berarti semakin tinggi keputusan inovasinya.

\section{Orientasi Nilai}

Orientasi nilai adalah peninjauan untuk menentukan mengenai usaha budidaya yang dianggap baik dan buruk oleh seseorang sesuai dengan tujuan instrumental ekonomi. Sebaran orientasi nilai rensponden pembudidaya udang dapat dilihat pada tabel 13. Tabel 13 memperlihatkan bahwa sebaran responden pembudidaya udang yang mempunyai orientasi nilai rendah adalah $0 \%$, sedang $100 \%$ dan tinggi $0 \%$. Artinya penilaian respoden terhadap inovasi budidaya udang yang dianjurkan cukup baik dan respek.

Berdasarkan hasil analisis uji statistik rank spearman orientasi nilai tidak memiliki hubungan yang nyata terhadap keputusan responden pada taraf uji $99 \%$. Hal ini dapat dilihat dari nilai koefisien korelasi $(r s=0,002)$. Artinya, nilai-nilai atau aturan yang ada pada masyarakat masih turut berperan dalam pengambilan keputusan inovasi budidaya udang.

\section{Sifat Inovasi}

Sifat inovasi yang diamati dilihat dari segi keuntungan relatif baik secara sosial maupun ekonomi, kesesuaian berdasarkan norma setempat maupun ide sejenis yang diperkenalkan, kerumitan dalam pelaksanaan inovasi dan kemudahannya yang dapat diamati hasilnya. Keadaan persepsi responden terhadap sifat inovasi teknologi budidaya udang dapat dilihat pada tabel 14 .

Tabel 14 menunjukkan bahwa persepsi responden pembudidaya terhadap inovasi didominasi oleh kategori sedang dengan persentase sebaran responden $80 \%$. Artinya bahwa, apresiasi pembudidaya udang di Tanah Laut terhadap inovasi teknologi budidaya sudah cukup baik. meskipun dalam penerapan paket teknologi budidaya udang tersebut masih banyak kendalanya seprti modal. Uji analisis statistik rank spearman menunjukkan bahwa sifat inovasi (keuntungan relatif, kesesuaian, kemudahan) berhubungan positif dengan pengambilan keputusan inovasi. Hal ini dapat dilihat dari nilai koefisien korelasi keuntungan relatif $\left(0,789^{* *}\right)$, keseuaian $(0,306)$ dan kemudahan untuk dicoba $\left(0,439^{*}\right)$. Artinya bahwa sifat inovasi merupakan faktor yang berpengaruh terhadap proses pengambilan keputusan inovasi

Tabel 13. Sebaran Orientasi Nilai Responden Pembudidaya Udang di Tanah Laut. Table 13. Distribution of Respondent Value Orientation of Shrimp Farmer in Tanah Laut.

\begin{tabular}{llrr}
\hline \multirow{2}{*}{ No } & Kriteria/Criteria & \multicolumn{2}{c}{ Responden/Respondents } \\
\cline { 2 - 4 } & Jumlah/ Total & $\begin{array}{c}\text { Persentase/ } \\
\text { Presentage (\%) }\end{array}$ \\
\hline 1 & Tinggi /High(19-25) & 0 & 0 \\
2 Sedang / Medium (13-18) & 20 & 100 \\
3 & Rendah /Low (5-12) & 0 & 0 \\
& Jumlah/Total & 20 & 100 \\
\hline
\end{tabular}


Tabel 14. Sebaran Responden Menurut Persepsinya Terhadap Sifat InovasiTeknologi Budidaya Udang di Tanah Laut.

Table 14. Respondent Distribution on Their Perception of Shrimp Culture Technology Innovation in Tanah Laut.

\begin{tabular}{|c|c|c|c|}
\hline \multirow[b]{2}{*}{ No } & \multirow[b]{2}{*}{ Kriteria/Criteria } & \multicolumn{2}{|c|}{ Responden/ Respondents } \\
\hline & & Jumlah/Number & $\begin{array}{c}\text { Persentase/Presentage } \\
(\%)\end{array}$ \\
\hline & Tinggi / High & 0 & 0 \\
\hline 2 & Sedang /Medium & 16 & 80 \\
\hline 3 & Rendah /Low & 4 & 20 \\
\hline & Jumlah/Total & 20 & 100 \\
\hline
\end{tabular}

teknologi. Hal ini dapat terjadi karena bagaimanapun, responden pasti akan tertarik dan mau memutuskan menerima inovasi sepanjang inovasi tersebut menguntungkan dan sesuai bagi mereka terutama secara ekonomis menambah dapat menambah pendapatan mereka.

\section{Keikutsertaan Dalam Kelompok}

Hampir seluruh responden pembudidaya udang di Tanah Laut ikut bergabung dalam kelompok pembudidaya. Hal ini dapat dilihat dari sebaran keikutsertaan responden dalam kegiatan kelompok pembudidaya pada tabel 15. Tabel 15 menunjukkan bahwa responden sebaran responden yang terlibat dalam kegiatan kelompok pembudidaya yakni $90 \%$ tergolong kategori tinggi. Sedangkan Kategori persentase kategori sedang adalah $10 \%$ dan kategori rendah $0 \%$. Kelompok tani di Tanah laut cukup mempunyai peranan dalam membantu pembudidaya dalam memecahkan masalah budidaya terutama yang menyangkut masalah hama penyakit. Hasil analisis rank sperman menunjukkan bahwa Tidak terdapat hubungan yang nyata pada taraf $99 \%$ antara sering keikutsertaan responden dalam kelompok dengan pengambilan keputusan inovasi budidaya udang. Hal ini dapat dilihat dari nilai koefisien korelasi $(r s=0,021)$. Ini berarti semakin sering seseorang ikut serta dalam kegiatan kelompok, bukan menentukan semakin tinggi pula keputusannya untuk mengadopsi teknologi budidaya udang.

\section{Akses Modal}

Modal merupakan salah satu penentu pembudidaya dalam melakukan usaha budidaya udang. Dimana untuk menerapkan satu paket teknologi yang dianjurkan membutuhkan biaya yang tidak sedikit. Keadaan akses modal responden

Tabel 15. Sebaran Keikutsertaan Responden Pembudidaya Udang dalam kelompok di Tanah Laut.

Table 15. Respondent Distribution of Group of Attendance of Shrimp Culture in Tanah Laut.

\begin{tabular}{llrr}
\hline \multirow{2}{*}{ No Kriteria/Criteria } & \multicolumn{2}{c}{ Responden/Respondents } \\
\cline { 2 - 4 } & & Jumlah/ Total & $\begin{array}{c}\text { Persentase/Presentage } \\
\text { (\%) }\end{array}$ \\
\hline 1 & Tinggi /High & 19 & 90 \\
2 & Sedang /Medium & 1 & 10 \\
3 & Rendah /Low & 0 & 0 \\
& Jumlah/Total & $\mathbf{2 0}$ & $\mathbf{1 0 0}$ \\
\hline
\end{tabular}


pembudidaya udang di Tanah Laut dapat dengan keputusan yang buatnya (Rogers dilihat pada tabel 16 . dalam Hanafi, 1981).

Tabel 16. Sebaran Akses Modal Responden Pembudidaya Udang di Tanah Laut. Table 16. Distribution of Capital Access of Shrimp Farmer in Tanah Laut.

\begin{tabular}{llrr}
\hline \multirow{2}{*}{ No } & Kriteria/Criteria & 0 & \multicolumn{2}{c}{ Responden/Respondents } \\
\cline { 3 - 4 } & \multicolumn{2}{c}{$\begin{array}{c}\text { Persentase/Percentage } \\
\text { (\%) }\end{array}$} \\
\hline 1 Mudah/ Easy & 6 & 0 \\
2 & Agak Sulit / Medium & 14 & 30 \\
3 & Sulit / Hard & $\mathbf{2 0}$ & 70 \\
\multicolumn{2}{r}{ Jumlah/ Total } & & $\mathbf{1 0 0}$ \\
\hline
\end{tabular}

Tabel 16 datas menunjukkan bahwa $70 \%$ responden pembudiaya mendapat kesulitan dalam mengakses modal ke perbankkan. Sedangkan $30 \%$ responden menyatakan agak sulit untuk mengakses modal ke perbankan. Keadaaan ini tidak membantu pembudidaya dalam memecahkan kesulitan permodalan. Meskipun ada bantuan yang diberikan oleh pemerintah, namun tidak mencukupi untuk biaya operasional budidaya udang. Hasil analisis rank sperman menunjukkan bahwa adanya hubungan yang signifikan antara akses modal dengan pengambilan keputusan responden untuk mengadopsi inovasi budidaya udang. Hal ini dapat dilihat dari nilai koefisien korelasi ( $r s=0,747^{* *}$ ) yang menunjukkan adanya hubungan yang nyata antara akses modal dengan pengambilan keputusan inovasi.

\section{Dissonansi (Ketidakselarasan) inovasi}

Jika terdapat perbedaan antara sikap seseorang terhadap inovasi dengan keputusan yang dibuatnya, maka terjadilah dissonansi inovasi. Dissonansi inovasi merupakan tipe ketidakselarasan kognitif. Ketidakselarasan adalah kenyataan psikologis yang dapat menimbulkan seseorang merasa tidak nyaman dengan keputusan yang dibuatnya, sehingga timbul sikap yang berbeda terhadap suatu inovasi
Pada kasus penerapan teknologi budidaya udang, dissonansi inovasi (ketidakselarasan inovasi) terjadi pada setiap lokasi penelitian. Ketidakselarasan inovasi ini sangat jelas terlihat dari penerapan paket teknologi yang tidak utuh oleh masyarakat pembudidaya udang. Berdasarkan hasil penelitian, ada beberapa aspek yang menyebabkan terjadinya dissonansi (ketidakselarasan) inovasi antara lain: aspek kelembagaan, aspek teknologi, dan aspek karakteristik masyarakat.

\section{Aspek Kelembagaan}

Strategi pembangunan kelautan dan perikanan yang dipicu oleh inovasi teknologi perikanan menuntut perlunya kelembagaan teknologi perikanan yang kondusif bagi penemuan teknologi tepat guna dan efektif dalam mendiseminasikan teknologi baru. Isu pokok dalam penataan kelembagaan teknologi perikanan ini ialah bagaimana merancang tata hubungan antara tiga subsistem utama kelembagaan teknologi, yaitu; lembaga riset/penelitian, lembaga penyuluhan dan prktisi agribisnis. Dalam hal ini terdapat tiga alternatif model kelembagaan teknologi (Uphotl, 1995, lacy, 1995) yaitu model vertikal, model horizontal dan model triangular. Pada model vertikal, lembaga riset/ penelitian bertugas untuk mendapatkan 
terobosan teknologi, setelah dilakukan pengujian dan adaptasi, teknologi yang telah siap guna selanjutnya diserahkan kepada lembaga penyuluhan, yang selanjutnya melakukan upaya diseminasi kepada para praktisi agrisbisnis dan pengguna akhir teknologi tersebut. Pada model vertikal ini lembaga riset tidak berinterkasi dengan praktisi agribisnis yang menjadi klien utama. Disamping itu, organisasi-organisasi internal di dalam subsistem lembaga penyuluhan dan lembaga riset/peneelitian juga berbentuk vertikal. Interaksi antar subsitem hanya berlangsung diantara pimpinan lembaga sehingga peneliti maupun penyuluh lapangan bekerja berdasarkan pengarahan dari atas ke bawah (top down). Pola kelembagaan seperti inilah yang cenderung digunakan di indonesia hingga sampai saat ini. Pada hakekatnya, model ini didasarkan pada upaya penyediaan teknologi tanpa memperhatikan ketepatgunaannya.

Kelembagaan teknologi model vertikal tidak memungkinkan bagi peneliti untuk mengetahui kebutuhan pengguna/stakeholder maupun bagi pengguna/stakeholder untuk menyampaikan kebutuhannya kepada para peneliti. Pada kelembagaan model vertikal interaksi anatara pengguna (pembudidaya), penyuluh dan peneliti praktis tidak mungkin secara langsung. Dengan demikian kelembagaan teknologi model vertikal tidak cocok pada pembangunan agroindustri karena peluang untuk timbulnya ketidaksesuaian anatara teknologi yang dibutuhkan dengan yang ditemukan peneliti sangat besar, selain itu waktu yang dibutuhkan dalam proses penyampaian (diseminasi) teknologi terlalu Iama. Berikut bagan alir yang menggambarkan kelembagaan teknologi model vertik

Pada model horizontal, alih teknologi bersifat "pengiriman ke luar" bukan "kebawah". Sub sistem lembaga pebnelitian bernaung dalam struktur organisasi yangterpisah dari subsistem penyuluhan, pengguna teknologi/ stakeholder yang sudah berpendidikan dan mampu secara ekonomis, berhubungan langsung dengan penyuluh atau peneliti. Bahkan pengguna teknologi tersebut menyediakan dana bagi peneliti untuk mendapatkan teknologi yang dibutuhkannya.

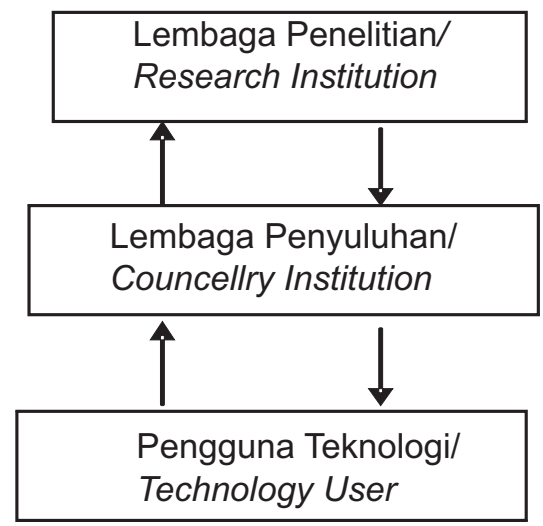

Gambar 4. Kelembagaan Teknologi Model Vertikal. Ficture 4. Institutional of Vertical Model Technology.

Dalam model ini praktis hanya cocok di negara-negara maju yang penggunanya sudah berpendidikan tinggi dan memiliki skala usaha yang cukup besar

Pada model triangular, pengguna teknologi/ stakeholder diperlakukan sebagai mitra sejajar dari para peneliti dan penyuluh dalam proses penelitian, disseminasi, dan penerapan teknologi. Pengguna teknologi, penyuluh dan peneliti berkomunikasi secara interaktif dan langsung sebagai mitra kerja yang sejajar. Pengguna teknologi ikut serta dalam mengarahkan program penelitian, sehingg teknologi yang dihasilkan instansi riset sesuai dengan kebutuhan nyata dan dapat didiseminasikan hasilnya secara cepat. Peneliti juga bekerjasama langsung dengan pengguna teknologi/ stakeholder dan penyuluh dalam mengidentifikasi permasalahan yang dihadapi dan maupun dlam penerapan teknologi baru. Berikut bagan yang menggambarkan kelembagaan model triangulasi

Berdasarkan hasil penelitian, aspek Kelembagaan merupakan salah satu faktor 


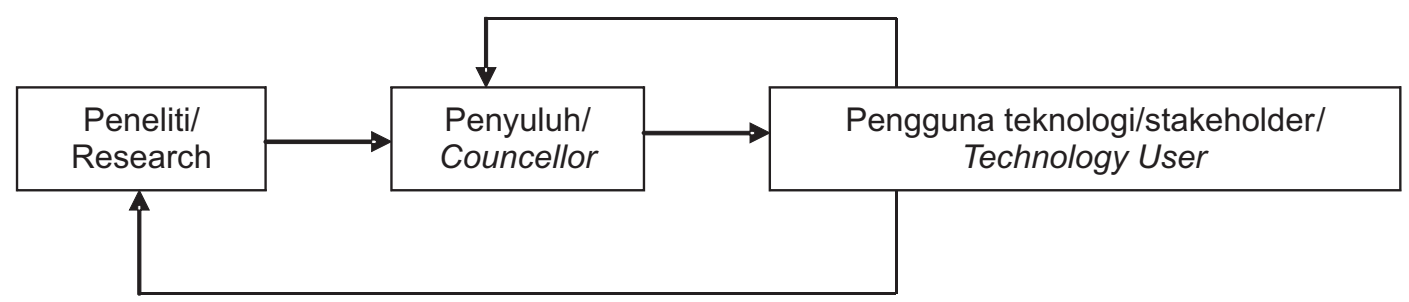

Gambar 5. Kelembagaan Teknologi Model Horizontal.

Figure 5. Institutional of Horizontal Model of Technology.

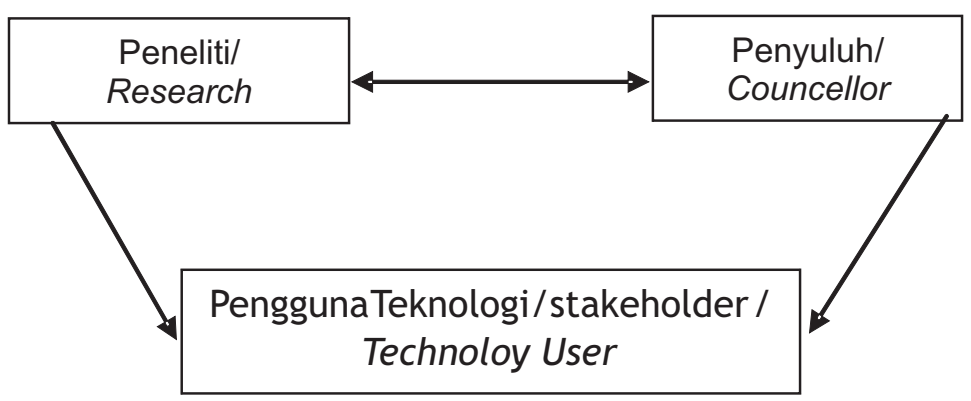

Gambar 6. Kelembagaan Model Triangulasi. Ficture 6. Institution of Triangulation Model.

yang menyebabkan tejadinya dissonansi inovasi. Aspek kelembagaan ini terdiri dari Kelembagaan pemerintah, kelembagaan Penyuluh dan kelembagaan penunjang/kelembagaan masyarakat.

\section{IV.KESIMPULAN DAN IMPLIKASI KEBIJAKAN}

Hasil riset menujukkan bahwa tipe pengambilan keputusan dalam pengadopsian paket teknologi budidaya udang pada masingmasing lokasi penelitian cenderung pada pengambilan keputusan secara individu.

Dilihat dari persentase pengambilan keputusannya di Tanah Laut 66,66 persen dilakukan secara individu, 16,67 persen diintervensi kelompok dan pemerintah.

Faktor-faktor yang berhubungan dengan proses pengambilan keputusan adopsi inovasi adalah faktor umur, pendidikan, pendidikan formal, pendapatan, pengalaman berusaha budidaya, kekosmopolitan, pola nafkah, tingkat kepercayaan, orientasi nilai dan keberanian mengambil resiko, keuntungan relatif, kesesuaian dan kemudahan untuk dicoba, reference group, akses modal dan ketersediaan sumber informasi.

\section{DAFTAR PUSTAKA}

Atmosudidjo, S.P., 1982. Beberapa Pandangan Umum Tentang Pengambilan Keputusan (Decition Making). Penerbit Ghalia Indonesia.

Danakusumah, E., dan S. Putro. 2003. Pedoman Investasi Komoditas Udang di Indonesia. Direktorat Sistem Permodalan dan Investasi. Direktorat Jenderal Peningkatan Kapasitas Kelembagaan dan Pemasaran. Departemen Kelautan dan Perikanan. Jakarta.

De cecco, 1989. Educational Physicology. Diedit oleh Joh P. De Cecco Prantice Hall. Inc. Englewood Cliffs New Jersey. 
Ganzali, 1988. Media Siaran Dalam Pembangungan Pertanian di Negaranegara Dunia Ketiga. Dalam Komunikasi Massa dan Pembangunan Pedesaan di Desa-desa Berkembang. Gramedia. Jakarta.

Hanafi, A., 1987. Memasyarakatkan Ide-ide Baru. Penerbit Usaha Nasional. Surabaya, Indonesia.

Havclock.R.G., 1971. Planning For Innovation Through Dissemination an Utilization of Knowlage. The University Of Michigan, An Arbor, Michigan.

Inspektorat Jenderal Departen Kelautan dan

Perikanan, 2003. Bedah Program Inbudkan. Diskusi Panel. Jakarta.

Jahi, A.,1991. Pengaplikasian Prinsipprinsip Belajar Dalam Bidang Pembangunan Pertanian. Makalah Bagi Pelatihan Penyuluh. Institut Pertanian Bogor, Bogor.

IStiana.1998. Analisis Sistem Komunikasi

Usahatani Padi Pada Petani Koperative. Study Kasus di Kecamatan embak Lemo Kampar. Riau, Thesis IPB.

Lionberger, Herber F. dan Gwin Paul H.,1992. Communication Strategics: A Guide For Agricultural Change Agent. The Lusterstate IPP, Us.

Latif, Am 1995. Tingkat Adopsi Teknologi Usahatani bekas peladang berpindah, ThesisProgram Pasca Sarjana. IPB

Kamaluddin, L.M., 1994. Strategi Penyiapan dan Pengembangan Kualitas SDM Pada Pembangunan Agribisnis Perikanan Indonesia. Makalah pada Seminar Sehari Himpunan Sosial Ekonomi Perikanan. Institut Pertanian Bogor, Bogor.
Karyo. F., dan P. Simatupang, 1997. Inovasi Teknologi Pertanian Sebagai Upaya Peningkatan Produktivitas dan Pertumbuhan Agroindustri Pedesaan. Badan Litbang Pertanian. Deptan. Jakarta.

Kusai, 1996. Tingkat Adopsi Petani Ikan Terhadap Teknologi Budidaya Ikan Dalam Karamba Terapung. Studi Kasus di Kecamatan Bangkinang Barat, Kabupaten Kempar, Propinsi Riau. Tesis. Institut Pertanian Bogor.

Latif, A. 1995.Tingkat Adopsi Teknologi Usahatani

Mardikanto, T., 1998. Strtegi Komunikasi Pembangunan. PT. Balai Pustaka (Persero). Jakarta.

Randal, A.T. 1987. Resource Econometrics. 2th Edition. John Wiley \& Son. Ney York, Chicerter. Brisbane, Toronto, Singapore.

Rogers, 1983. Diffition of Innovation. Third Edition. The Free Press. A Diffution of Macmillan Publishing Co. Inc. New York.

Ogers dan Shoemaker, 1991. Commucation of bivation, The Free Press, New York

Slamet, 1978. Kumpulan Bahan Bacaan Penyuluhan Pertanian. Edisi Ketiga. Institut Pertanian Bogor, Bogor.

Soekarwati, 1988. Prinsip Dasar Komunikasi Pertanian. Universitas Indonesia, Jakarta.

Sugiarti, A., 2001. Keputusan Pengadopsian Teknologi Pengupasan Kepiting. Studi Kasus Pada Keluarga Nelayan di Kecamatan Tupabbiring Kabupaten Pangkep Sulawesi Selatan. Tesis. Institut Pertanian Bogor. 